\title{
KEMATANGAN KARIR SISWA SMA
}

\author{
H.R. Partino \\ Universitas Cenderawasih
}

\begin{abstract}
This research was aimed to verify a model of career maturity on High School students. The model suggests that career maturity is affocted by many factors, ie. counseling service, perception of study major, Iffe history, self-efficacy and academic achievement.

Research subjects consisted of 616 SMA students. Data were collected using career maturity inventory, psychological scale, and questionnaire. These instruments had been adapted in Indonesian and their reliability and validity had been reestablished. Structural equation model was developed to analyze career maturity determinant factors. Outcomes of the analysis were used to verify the career maturity model and to find out direct, indirect and total effects.

The research results showed that the theoretical model of career maturity is supported by empirical data, namely the eight category of measurement. Specifically, the research results are: 1) counseling service, perception of study major and iffe history had a significant effect on self-efficacy; 2) counseling service, perception of study majoring and life history had a significant effect on academic achievement; and 3) self-efficacy had a significant effect on academic achievement.
\end{abstract}

Key words: career maturity, counseling services, perception of study majoring, the history, self-eficacy, and academic achievement.

\section{Pengantar}

Kematangan karir oleh ahli psikologi diartikan sebagai kesiapan individu untuk menyelesaikan tugas-tugas perkembangan karir seiring dengan perkembangan biologis dan sosialnya (Super, 1994), kesiapan sikap dan kompetensi individu untuk melakukan pilihan karir yang tepat (Crites, 1986) dan keslapan mengambil keputusan karir yang realistik (Lundberg dkk, 1997). Kematangan karir semestinya telah dimiliki siswa SMA (Sekolah MenengahAtas). Siswa SMAharus melakukan pilihan karir, yakni melanjutkan studi atau memasuki dunia kerja.

Dalam kenyataannya, konsep perkembangan karir dan kematangan karir umumnya belum menjadi perhatian serius, baik di lingkungan sekolah, dunia kerja, maupun masyarakat Indonesia pada umumnya. Tidak kurang dari itu, perhatian Ifmuwan psikologi terhadap teori perkembangan karir juga masih kurang, sehingga hasil studi kematangan karir sangat terbatas. Hal ini cukup memprihatinkan, karena sebagaimana diungkapkan Coertse dan Schepers (2004), kematangan karir sesungguhnya telah diteliti, diukur dan menjadi bahan diskusi hangat sejak 40 tahun lalu.

Sejauh ini para ahli psikologi melalui berbagai penelitiannya mencoba mengidentifikasi faktor-faktor apa saja yang mempengaruhi kematangan karir. Super (1994) menemukan bahwa kematangan karir dlpengaruhi oleh faktor biologis-geografis, psikologis dan sosio-ekonomis. Naidoo (1998), Betz dan Hackett (1981), Lent dkk (1987), Creed and Patton (2003) menemukan pengaruh efikasi-diri terhadap kematangan karir. Bolles (1993) meneliti hubungan riwayat hidup dengan kematangan karir. Pritchard (1984), Pavlak dan Post-Kammer (1985) menemukan 
pengaruh bimbingan terhadap kematangan kari. West (1988) meneliti prestasi akademik dan kematangan karir. Berdasarfaktor-faktor d atas, disusun model kematangan karir yang dipengaruhi oleh layanan blmbingan, persepsi penjurusan, riwayat hidup, efikasidíi dan prestasi akademik.

Studi ini ingin menjawab pertanyaan tentang bagaimana model kematangan karir siswa SMA? Secara operasional, masalah penelitian dirumuskan sebagai berikut: bagaimana pengaruh layanan blmbingan, persepsi penjurusan, riwayat hidup, efikasidiri dan prestasi akademik terhadap kematangan karir? Pertanyaan tambahan yang ingin djjawab adalah (1) bagaimana pengaruh layanan bimbingan, persepsi penjurusan dan riwayat hidup terhadap efikasi-dirl?; (2) bagaimana pengaruh layanan bimbingan, persepsl penjurusan dan riwayat hidup terhadap prestasi akademlk?; (3) bagaimana pengaruh efrkasi-diri terhadap prestasi akademik?

\section{Dasar Teori}

Kematangan karir merupakan kesiapan individu untuk mengambil keputusan karir yang realistik (Lundberg dkk, 1997), kesiapan sikap dan kompetensi Individu untuk melakukan pilihan karir seçara tepat (Crites, 1974). Kematangan karir sebagai sebuah konstruk memilikl dua dimensi, yakni sikap pilihan karir dan kemampuan pilihan karir.

Perkembangan karir merupakan bagian integral dari perkembangan individu (Crites, 1974). National Career Development Association (NCDA) (2003) membatasi perkembangan karir sebagai keseluruhan konstelasi psikologis, sosiologis, pendidikan, ekonomi, fisik dan faktor-faktor peluang yang berpadu untuk mempengaruhi sifat dan pentingnya kerja dalam seluruh rentang kehidupan. Casto (2004) menegaskan perkembangan karir sebagai proses yang terus menerus, mencakup aspek perencanaan dan strategi berdasarkan informasi tentang diri sendiri, dunia kerja, pemasangan kedua hal tersebut, dan tindakan yang akan diambil untuk kehidupan masadepan.

Teori perkembangan karir dapat dikelompokkan ke dalam pendekatan kepribadian, pendekatan trait dan faktor, teori perkembangan dan teori pengambilan keputusan (Osipow, 1996). Teori Super sebagai bagian dari teori perkembangan dipilih sebagal dasar pengembangan model kematangan karir. Brown (1996) menegaskan bahwa Teori Super paling komprehensif, menjadi acuan teori-teori lain dan selalu dinamis mengikuti perkembangan zaman. Teori Super dilengkapi dengan temuan Naidoo (1998), Lent dkk (1987), Creed and Patton (2003) tentang efikasi-diri, Bolles (1993) ten lang riwayat hidup, Abdullah (1986), Abimanyu (1990), Partino (1990), Pavlak \& Post-Kammer (1985), Pritchard (1984), dan West (1988) tenlang layanan bimbingan dan prestasl akademik.

Super (1994) menyatakan bahwa siswa SMA tergolong pada tahap eksplorasi (masa remaja, 14-24). Tugas-tugas perkembangan karir pada tahap ini adalah: (1) mengembangkan konsep-diri yang reallstik; (2) belajar lebih banyak tenlang kesempatan yang luas; (3) mulai memilih jurusan di perguruan tinggi; (4) memeriksa pilihanpilihan pekerjaan secara tentatif; dan (5) memberikan waktu lebih sedikit untuk kegiatan kesenangan atau hobi.

Kematangan karir merupakan tema sentral dalam pembahasan teori perkembangan karir. Teqi kematangan karlr Crites (1974) merupakan penyempurnaan konsep Super tentang Career Patterns Study dan dithami oleh konsep struktur kecerdasan dari Vernon. Berdasarkan hasil studinya, Crites (1986) membuat sebuah model kematangan karir remaja. Model ini terdiri dari dua dimensi, yakni kompetensi pilihan karir dan sikap pilihan karir. Konsep kematangan karir Crites digunakan secara konsisten dan paling luas (West, 1988), termasuk dalam penelitian-penelitian eksperimen (Lundberg dkk, 1997), bahkan sejak tahun 70 -an dan sangat berguna untuk studi perkembangan kari, menyaring orang yang belum matang karir, meningkatkan kematangan karir, dan menilai pendidikan karir (Rojewski dkk, 1995). Mau (2001) menegaskan Inventori Kematangan Karir 
Crites tetap menjadi pilihan favorit para peneliti.

Berikut disajkan urajan tentang faktorfaktor yang dipertimbangkan berpengaruh terhadap kematangan karir.

\section{Layanan Bimbingan dan Kematangan Karir.}

Program bimbingan di SMA merupakan bagian integral dalam kurikulum. Program lni secara resmi berlaku sejak Kurikulum SMA 1975 (Departemen Pendidikan dan Kebudayaan, 1975), bukan sekedar layanan tambahan (Gysbers, 1998). Kurikulum SMA 1994 lebih menitikberatkan pada pengembangan materi afektif belajar, yaitu pengembangan sikap, nilai dan kepribadian (Munandir, 1996).

Esbroek dan Watts (1998) membedakan bimbingan ke dalam tiga jenis, yakni bimbingan karir, pribadi dan pendidikan. The isle of Wight County School Board (1996) membagi layanan $k \theta$ dalam bimbingan akademik, karir, pribadi dan sosial. Departemen Pendidikan dan Kebudayaan (1996) mengadopsi bimbingan dan membedakan ka dalam bimbingan pribadi, sosial, belajar dan karir.

Layanan bimbingan di sekolah diyakini berpengaruh terhadap kematangan karir. $\mathrm{Hal}$ ini didukung oleh studi Abdullah (1985), Abimanyu (1990), Partino (1990), Pritchard (1984). Pavlak dan Post kammer (1995). Hasil-hasil penelitian tersebut menemukan bahwa layanan bimbingan berhubungan secara signifikan dengan kematangan karir. Hal ini sesuai dengan teori Super(1994)

\section{Persepsi Penjurusan dan Kematangan Karir.}

Secara fisiologis, persepsi mengact pada suatu proses penginderaan, yakni adanya objek atau objek-objek yang menimbulkan rangsangan yang mengenai alat indera. Alat indera menerima rangsangan, kemudian dilanjutkan oleh syaraf sensoris ke pusat susunan syaraf (otak). Otak bertugas memproses rangsangan yang masuk, mengorganisasi, dan menginterprotasi, sehingga individu dapat menyadari hal-hal yang diterima.
Proses kegiatan di otak ini disebut sebagai proses psikologis. Kegiatan ini merupakan proses terakhir dari persepsi yang merupakan proses persepsi yang sebenamya (Walgito, 2002).

Persepsi siswa tentang penjurusan merupakan reaksi terhadap penempatan siswa ke dalam salah satu jurusan. Persepsi dapat dibedakan ke dalam persepsi yang akurat dan persepsi yang keliru. Studi yang meneliti persepsi terhadap penjurusan di SMA, sepengetahuan penulis belum ditemukan.

Penempatan individu pada jurusan tertentu merupakan realisasi hak individu atas segala kewajibannya. Penghargaan ini memungkinkan tumbuhnya dorongan untuk melaksanakan kegiatan berkaitan dengan jurusan tersebut, temasuk belajar. Motivasi untuk belajar akan mempengaruhi hasil belajar. Hasil belajar ini berkaitan dengan kematangan karir, di mana mereka yang memiliki hasil belajar yang tinggi lebih realistik dalam membual rencana masa depan (Super dalam Osipow, 1983). Jadi, persepsi penjurusan berhubungan langsung dan tidak langsung dengan kematangan karir.

\section{Pengaiaman Pribadi dan Kematangan} Karír.

Hammel (2001) menegaskan bahwa riwayat hidup atau pengalaman pribadi merupakan suatu gambaran individu yang relatlf lengkap, mencakup semua pengalaman di sekolah dan luar sekolah, karakteristik dirinya, dan hubungannya dengan keluarga. Hammel (2001) merinci riwayat hidup ke dalam pengalaman masa kanak-kanak dan remaja, terutama pada masa SD-SMA. Kegiatan berorganisasi. olahraga, kesenian dan bermain baik di lingkungan tempat tinggal maupun di sekolah merupakan bagian dari riwayat hidup (Hammel, 2001)

Partisipasi kegiatan di sekolah dan di luar sekolah berhubungan secara positif dan bermakna dengan kematangan karir (Super dan Overstreet dalam Osipow, 1983). Bolles (1993) menyatakan bahwa individu dapat memanfaatkan riwayat hidupnya dengan 
mengidentifikasi aspek-aspek menonjol dirinya sebagai bahan pertimbangan dalam mengambil keputusan karirnya. Jadi. pengalaman pribadi diyakini turut serta menentukan arah karir individu.

Effikasi Diri dan Kematangan Karir.

Efikasi-diri dibatasl sebagai keyakinan tentang kesanggupan diri untuk melakukan pekerjaan yang ditugaskan dengan sukses (Bandura, 1997). Model Bandura menjelaskan bahwa perubahan tingkah laku dicapai melaiui berbagal metode, sepert! bimbingan, pemodelan, persuasi dan reduksi kecemasan.

Teori efikasi-diri berguna untuk memahami dan meramaikan tingkah laku karir yang sesuai, seperti pilihan pekerjaan dan prestasi akademik. Hackett dan Betz (1981) mengemukakan bahwa efikasi-din menentukan rentang pemahaman karir dan pilihan akademik. Lent dkk (1987) membuktikan bahwa efikasi-diri berhubungan dengan pengambilan keputusan karir; mampu meramakan keberhasilan studi di perguruan tinggi. Selanjuinya Lent dkk (1987) menemukan bahwa teori efikasi-diri lebih mantap (robust) dalam menjelaskan dan meramalkan kinerja akademik mahasiswa. Efikasi-diri merupakan prediktor yang signifikan terhadap pertimbangan pilihan pekerjaan (Post-Kammerdan Smith, 1986), dan tingkah laku karir (Rolberg dkk 1987). Jadi, teori efikasi-diri Bandura (1997) telah teruji berdasarkan hasil penelitian lapangan.

Prestasl akademikdan Kematangan Karir.

Prestasi belajar merupakan wujud perpaduan dari segala potensi dan upaya individu dari yang bersifat biologis, psikologis dan sosio-ekonomik (Super, 1994). Prestasi akademik pada studi ini adalah nilai mumi hasil UUB.Abimanyu (1990), Partino (1990), dan West (1988) menemukan bahwa terdapat hubungan signifikan antara prestasi akademik dan kematangan karir. Keterampilan menguasai cara-cara memecahkan masalah akademik dapat digunakan untuk mengatasi masalah lainnya (memilih jurusan dan jenjang di perguruan tinggi, kursus-kursus atau pekerjaan kelak). Temuan tersebut sesuai dengan teorl Super (1994) tentang determinan kematangan karir.

\section{Hipotesis}

Berdasarkan analisis di atas, dapat dirumuskan hipotesis bahwa ada hubungan antara layanan bimbingan, riwayat hidup, persepsi penjurusan, efikasi diri, prestasi akademik dengan kematangan karir.

\section{Metode Penelitian}

Penelitian ini termasuk jenis penelitian korelasional (Shaughnessy \& Zechmeister, 1994), yakni berupaya mencari hubungan antara variabel yang satu dengan variabel lainnya dalam sebuah model. Subjek adaiah siswa kelas 3 (tiga) dari lima SMA Negeri dan lima SMA Swasta dengan status disamakan. Pada awal pengumpulan data, subjek sebanyak 684 siswa, terdiri dari laki-laki 371 dan perempuan 313 ; seteiah dilakukan verifikasi data, subjek tinggal 616 siswa, terdiri dari laki-laki 329 dan perempuan 287.

Terdapat dua konstruk variabel, yakni endogen dan eksogen (Ferdinand, 2000), atau dependen dan independen (Joreskog dan Sorbon, 1996). Peneititian ini terdiri dari enam variabel laten dan 21 variabel terukur. Variabel iaten dependen meliputi efikasi-diri, kematangan karir dan prestasi akademik. Variabel-variabel laten independen meliputi layanan bimbingan, persepsi penjurusan dan riwayat hidup.

Penelitian ini menggunakan enam instrumen, yakni Inventori Kematangan Karir Crites (IKK-C), Skaia Manfaat Layanan Bimbingan (SMLB), Skala Persepsi Penjurusan (SPP), Daftar Riwayat Hidup Hammel (DRH-H), Skaia Efikasi-diri Betz \& Hackelt (SED-BH), dan Daftar Nilai UUB. Sebagai catatan, kernatangan karir sebagai sebuah konstruk memiliki dua dimensi, yakni sikap pilihan karir dan kemampuan pilihan karir.

Seteiah diakukan analisis aiat ukur, diketahui bahwa seiuruh alat ukur memiliki reliabilitas yang memadai. Hal ini ditunjukkan oleh koefisien aipha sebagaimana dapat dilihat dalam Tabel 1. 
Tabel 1.

Rangkuman Koefisien Alpha

\begin{tabular}{|c|l|c|c|}
\hline No. & \multicolumn{1}{|c|}{ Jenis Alat Ukur } & Jumlah Butir & $\alpha$ - Cronbach \\
\hline 1 & Sikap pilihan karir & 25 & 0,9217 \\
\hline 2 & Kompetensi pilihan karir & 25 & 0,9032 \\
\hline 3 & Layanan bimbingan & 40 & 0,9192 \\
\hline 4 & Persepsi penjurusan & 23 & 0,9134 \\
\hline 5 & Efikasi diri & 25 & 0,9047 \\
\hline
\end{tabular}

Berdasarkan analisis alat ukur, diketahui pula bahwa semua alat ukur memiliki validitas yang memadai. Hal ini ditunjukkan ofeh koefisien korelasi aitem total sebagaimana dapat dilihat dalarn Tabel 2.

Tabel 2.

Rangkuman Koefislen Korelasl Altem-Total

\begin{tabular}{|c|l|c|c|}
\hline No. & \multicolumn{1}{|c|}{ Jenis Alat Ukur } & r-terendah & r-tertinggl \\
\hline 1 & Sikap pilihan karir & 0,3006 & 0,7817 \\
\hline 2 & Kompetensi pilihan karir & 0,3093 & 0,7568 \\
\hline 3 & Layanan bimbingan & $0,2965^{*}$ & 0,8810 \\
\hline 4 & Persep\$i penjurusan & $0,2983^{*}$ & 0,7998 \\
\hline 5 & Efikasi diri & $0,2957^{*}$ & 0,7041 \\
\hline
\end{tabular}

Catatan:

- dibulatkan menjadi 0,30

r 0,30 signifikan, berarti butir valid

Analisis faktor konfirmatori digunakan untuk mengukur dimensl-dimensi yang membentuk sebuah faktor (variabel laten) yang disebut sebagal model pengukuran (Joreskog dan Sorbon, 1996; Ferdinand, 2000). Tujuan analisis ini adalah untuk mengetahui apakah indikator-indikator sebagal variabel terukur mampu mencermlnkan sebuah model pengukuran. Hasii analisis faktor konfirmatori variabel independen menunjukkan bahwa model tidak didukung data. Berdasarkan kajian mendalam temadap hasil analisis faktor
Konfirmatori, ditengarai terdapat dua variabel terukur yang tidak slgnifikan. Pekerjaan berikutnya adalah melakukan modifikasi model dengan cara meniadakan dua variabel terukur yang tidak signifikan. Analisis faktor konfirmatori modifikasi adalah fit. Simpulan bahwa variabel teramati yang membentuk variabel laten independen dan variabel laten dependen diterima. Analisis model persamaan struktural digunakan untuk pengujian hipotesis model kematangan karir. 


\section{Hasil Penelitian}

\section{Hasii Uj Hipotesis}

Model teoritis tidak didukung data empiris, karena berdasarkan 8 kriteria pengujian, hanya terdapat satu kriteria (GFl) yang fit Langkah berikutnya melakukan modifikasi model. Model teoritis modifikasi sesuai dengan data empiris tentang pengaruh layanan bimbingan, persepsi penjurusan, riwayat hidup, efikasi-diri dan prestasi akademik terhadap kematangan karir. Secara terinci, berdasarkan delapan jenis uji data empiris, semua hasil analisis memenuhi kriteria pengujlan. Hipotesis tentang model terbukti, jadi hipotesis diterima. Analisis lanjutan dilakukan untuk mengetahui sumbangan total variabel independen terhadap kematangan karir. Hasil analisis persamaan struktural menunjukkan koefisien determinasi ( ) atas kematangan karir adalah $0,87(p=0.000$, $p<0.01$ ). Fakta ini menggambarkan bahwa 87 persen varians kematangan karir depat dijelaskan oleh layanan bimbingan, persepsi penjurusan, riwayat hidup, efikasi-diri dan prestasi akademik.

Adapun model persamaan struktural hubungan antara layanan bimbingan, persepsi penjurusan, riwayat hidup, efikasidiri dan prestasi akademik dengan kematangan karir adalah sebagai berikut:

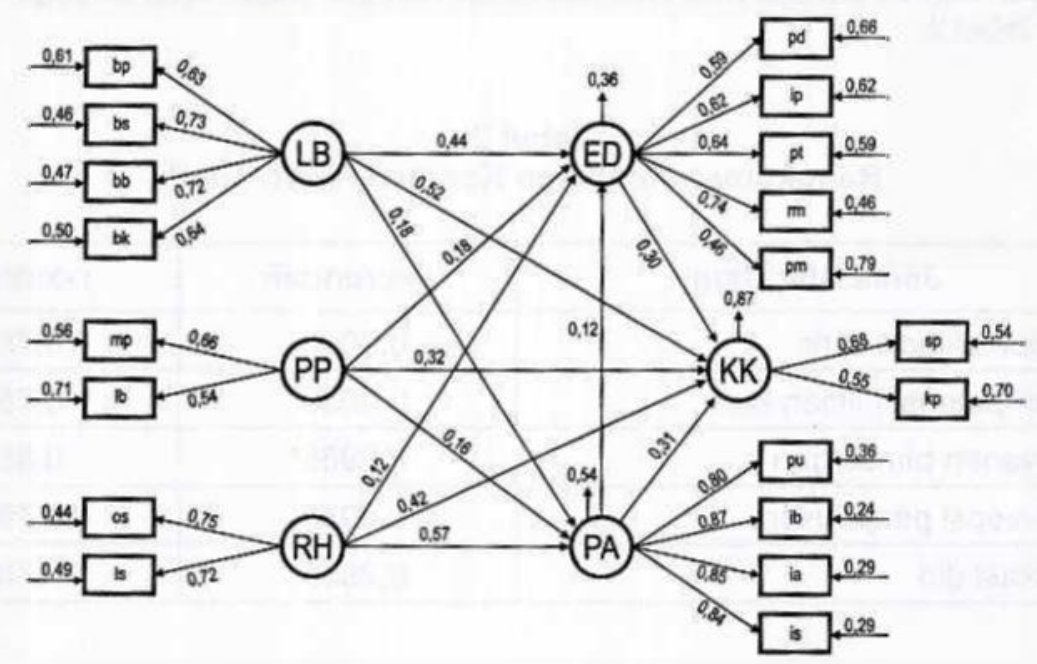

Gambar 1. Hasil analisis model persamaan struktura (berdasarkan efek total baku)

Chi-Square=156,93; of =137; $P$-value $=0,11700 ;$ RMSEA $=0,015$

\section{Keterangan}

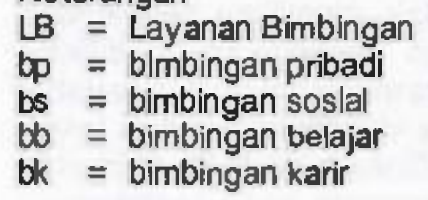

$E D=$ Efikasi-Diri

pd $=$ pemahaman dir

ip $=$ informasi

$\mathrm{pt}$ = pemilihan tujuan

$\mathrm{rm}$ = rencana masa depan

$\mathrm{pm}=$ pemecahan masalah

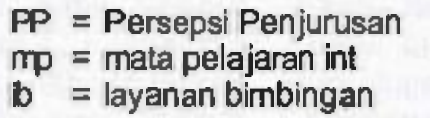

$\mathrm{PA}=$ PrestasiAkadernik

pu = mata pelajaran umum

ia = pelajaran ilmu alarn

b = pelajaran ilmu bahasa

is = peiajaran ilmu sosial

\author{
$\mathrm{RH}=$ Riwayat Hidup \\ os = organisasi sekolah \\ (OSIS-Non OSIS) \\ s = organisasi di luar sekolah \\ $\kappa K=$ Kematangan Karir \\ sp = sikap pilihan karir \\ $\mathrm{kp}=$ kemampuan pilihan karir
}


Hasil Analisis Tambahan

Hasil tambahan penelitian dirangkum dalam Tabel 3 berikut ini:

Tabel3

Rangkuman Hasil Analisls Regresi Ganda

\begin{tabular}{|c|l|c|c|c|c|l|}
\hline No. & \multicolumn{1}{|c|}{ Jenis Alat Ukur } & $\mathbf{N}$ & $\mathbf{R}$ & $\mathbf{R}^{2}$ & $\mathbf{p}$ & Simpulan \\
\hline 1 & $X_{1}, X_{2}, X_{3}$ terhadap $Y_{1}$ & 616 & 0,60 & 0,36 & 0,000 & Signifikan \\
\hline 2 & $X_{1}, X_{2}, X_{3}$ terhadap $Y_{3}$ & 616 & 0,74 & 0,54 & 0,000 & Signifikan \\
\hline 3 & $Y_{1}$ terhadap $Y_{3}$ & 616 & 0,35 & 0,12 & 0,000 & Signifikan \\
\hline
\end{tabular}

Keterangan:

$X_{1}$ = Layanan Bimbingan

$X_{2}=$ Persepsi Penjurusan

$X_{3}=$ Riwayat Hidup

$Y_{2}=$ Efikasi-Diri

$Y_{3}=$ PrestasiAkademik

1. Layanan bimbingan, persepsi penjurusan dan riwayat hidup berpengaruh positif terhadap efikasi-díri. Efek total baku layanan bimbingan terhadap efikasi-diri 0,44 dengan nilai-t $6,16>1,96$ adalah signifikan. Efek total baku persepsi penjurusan terhadap efikasi diri 0,18 dengan nilai-t $2,36,1,96$ adalah signifikan. Efek total baku riwayat hidup terhadap efikasi-diri 0,12 dengan nilal-t $2,05,1,96$ adalah signifikan. Ketiga aspek pengujlan hipotesis signifikan, hipotesis terbukti, jadi
Hipotesis tambahan yang berbunyi ada hubungan antara layanan bimbingan, persepsi penjurusan dan riwayat hidup dengan efikasi-diri, diterima. Berdasarkan hasil analisis persamaan struktural ditemukan koefisien determinasi atas efikasi-diri 0,36. Fakta ini menunjukkan bahwa 36 persen varians efikasi-diri dapat dijelaskan oleh variabel layanan bimbingan, persepsi penjurusan dan riwayat hidup. Hasil analisis dapat dilihat pad a tabel 4.

Tabel4

Layanan blmbingan, persepsl penjurusan, riwayat hldup, dan efikasl-diri

\begin{tabular}{|c|l|c|c|c|}
\hline \multirow{2}{*}{ No. } & \multirow{2}{*}{ Variabel } & \multicolumn{2}{|c|}{ Efikasi-diri } & \multirow{2}{*}{$\begin{array}{c}\text { Taraf Signifikansi 5 i/a } \\
\text { (t-teoritis - 0,96) }\end{array}$} \\
\cline { 3 - 4 } & & Efek total baku & t-empiris & \\
\hline 1 & Layanan bimbingan & 0,44 & 6,16 & Signifikan \\
\hline 2 & Persepsi penjurusan & 0,18 & 2,36 & Signifikan \\
\hline 3 & Riwayat hidup & 0,12 & 2,05 & Signifikan \\
\hline
\end{tabular}


2 Layanan bimbingan, persepsi penjurusan dar riwayat hidup berpengaruh secara positif terhadap prestasi akademik. Efek total baku layanan bimbingan terhadap prestasi akademik 0,18 dengan nilai-t $3,40,1,96$ adaiah signifikan. Efek total baku persepsi penjurusan terhadap prestasi akademik 0,16 dengan nilai-t 2,42, , ,96 adalah signifikan. Efek total baku riwayat hidup terhadap prestasi akademik 0,57 dengan nilai-t $9,78,1,96$ adalah signifikan. Ketiga aspek pengujian hipotesis signifikan, hipotesis terbukti.
Jadi hipotesis tambahan yang berbunyi ada hubungan antara layanar bimbingan, persepsi penjurusan dan riwayat hidup dengan prestasi akademik, diterima. Berdasarkan hasil analisis persamaan struktural ditemukar koefisien determinasi atas prestasi akademik 0,54. Fakta ini menunjukkan bahwa 54 persen varians prestasi akademik dapat dijelaskan oleh variabel layanan bimbingan, persepsi penjurusan dan riwayat hidup. Hasil analisis dapat dilihat pada tabel 5 .

Tabel 5.

Layanan bimbingan, persepsi penjurusan, riwayat hidup, prestasi akademik

\begin{tabular}{|c|c|c|c|c|}
\hline \multirow{2}{*}{ No. } & \multirow{2}{*}{ Variabel } & \multicolumn{2}{|c|}{ Efikasi-diri } & \multirow{2}{*}{$\begin{array}{c}\text { Taraf Signifikansi 5 \%, } \\
\text { (t-teoritis - 0,96) }\end{array}$} \\
\cline { 3 - 4 } & & Efok total baku & t-empiris & \\
\hline 1 & Layanan bimbingan & 0,18 & 3,40 & Signifikan \\
\hline 2 & Persepsi penjurusan & 0,16 & 2,42 & Signifikan \\
\hline 3 & Riwayat hidup & 0,57 & 9,78 & Signifikan \\
\hline
\end{tabular}

3. Efikasi-diñ berpenganuh positif terhadap prestasi akademik. Efek total baku efikasi-diri tehadap prestasi akademik
0,12 dengan nilai-t 2,$14 ; 1,96$ adaiah signifikan. Hasil anaiisis dapat dilihat pada tabel 6.

Tabol6.

Efikasi-diri berpengaruh positif temadap prestasl akademik.

\begin{tabular}{|c|c|c|c|c|}
\hline \multirow{2}{*}{ No. } & \multirow{2}{*}{ Varlabel } & \multicolumn{2}{|c|}{ Prestasi akademik } & \multirow{2}{*}{$\begin{array}{c}\text { Taraf Signifikansi 5 \%, } \\
\text { (t-teoritis-0,96) }\end{array}$} \\
\cline { 3 - 4 } & & Efok tolal bakw & t-empirts & \\
\hline 1 & Efikasi din & 0,12 & 2,14 & Signifikan \\
\hline
\end{tabular}

4. Efek langsung layanan bimbingan terhadap efikasi-diri 0,44 dan nilai-t 6,16, 1,96 adalah signifikan. Efek langsung layanan bimbingan terhadap kematangan kair 0,35 dan niliai-t 5,52, 1,96 adalah signifikan. Elek langsung layanan bimbingan terhadap prestasi akademik 0,13 dan nilaitt $2,26,1,96$ adalah signifikan. Efek langsung persepsi penjurusan terhadap efikasi-diri 0,18 dan nilait-t 2,36, 1,96 adalah signifikan. Efek langsung persepsi penjurusan terhadap kematangan karir 0,22 dan nilai-t $2,94,1,96$ adalah signifikan. Efek langsung persepsi penjurusan terhadap prestasi akademik kari 0,13 dan rilai-t 2,09, 1,96 adalah signifikan. Efek langsung riwayat hidup terhadap efikasi-diri 0,12 dan nilai-t 2,05 , 1,96 adalah signifikan. Efek langsung riwayat hidup terhadap kematangan karir 0,21 dan nilai-t 2,97, 1,96 adalah signifikan. Efek langsung riwayat hidup terhadap prestasi akademik 0,55 dan nilai-t $9,64,1,96$ adalah signifikan. Semua nilai-t signifikan, jadi terdapat efek langsung variabel independen terhadap variabel dependen. Hasil analisa dapatdilihat pada tabel 7 . 
Tabel 7.

Efek langsung baku layanan bimbingan, persepsi penjurusan dan riwayat hidup terhadap efikasi-dirí, kematangan karír dan prestasi akademlk

\begin{tabular}{|c|l|c|c|c|c|c|c|}
\hline \multirow{2}{*}{ No. } & \multirow{2}{*}{ Independen } & \multicolumn{2}{|c|}{$\begin{array}{c}\text { Layanan } \\
\text { Bimbingan (Ksi-1) }\end{array}$} & \multicolumn{2}{|c|}{$\begin{array}{c}\text { Persepsi } \\
\text { Penjurusan (Ksi-2) }\end{array}$} & \multicolumn{2}{|c|}{$\begin{array}{c}\text { Riwayat } \\
\text { Hidup (Ksi-1) }\end{array}$} \\
\cline { 3 - 8 } & & Efek & t-empiris & Efek & t-mpiris & Efek & t-mpiris \\
\hline 1 & Efikasi-diri (Eta-1) & 0,144 & $6,16^{*}$ & 0,18 & $2,36^{*}$ & 0,12 & $2,05^{*}$ \\
\hline 2 & Kematangan karir (Eta-2) & 0,35 & $5,22^{*}$ & 0,22 & $2,94^{*}$ & 0,21 & $2,97^{*}$ \\
\hline 3 & Prestasi akademik (Eta-3) & 0,13 & $2,16^{*}$ & 0,13 & $2,09^{*}$ & 0,55 & $9,64^{*}$ \\
\hline
\end{tabular}

Keterangan : $t>1,96=$ Signifikan

5. Efek tidak langsung layanan bimbingan terhadap kematangan karir 0,17 dan nilai-t 4,41 , 1,96 adalah signifikan. Efek tidak langsung layanan bimbingan terhadap prestasi akademik 0,05 dan nilai-t 2,02 , 1,96 adalah signifikan. Efek tidak langsung persepsi penjurusan terhadap kematangan karir 0,10 dan nilai-t 2,91 > 1,96 adalah signifikan. Efek tidak langsung riwayat hidup terhadap kematangan karir 0,21 dan nilait 4,41, 1,96 adalah signifikan. Semua nilai-t signifikan, jadi terdapat efek tidak langsung layanan bimbingan terhadap kematangan karir dan prestasi akademik; persepsi penjurusan terhadap kematangan karir; dan riwayat hidup terhadap kematangan karir. Efek tidak langsung persepsi penjurusan terhadap prestasi akademik 0,02 nilai-t 1,65 dan riwayat hidup terhadap prestasi akademik 0,01 nilai-t 1,67. Kedua nilal-t c 1,96 adalah tidak signifikan, jadi tidak terdapat efek tidak langsung. Hasil analisa dapat dilihat pada tabel 8 .

Tabel 8.

Efek tidak langsung baku variabel independen terhadap variabei dependen

\begin{tabular}{|c|l|c|c|c|c|c|c|}
\hline \multirow{2}{*}{ No. } & \multirow{2}{*}{ Independen } & \multicolumn{2}{|c|}{$\begin{array}{c}\text { Layanan } \\
\text { Bimblngan (Ksi-1) }\end{array}$} & \multicolumn{2}{|c|}{$\begin{array}{c}\text { Persepsi } \\
\text { Penjurusan (Ksi-2) }\end{array}$} & \multicolumn{2}{|c|}{$\begin{array}{c}\text { Rlwayat } \\
\text { Hidup (Ksi-1) }\end{array}$} \\
\cline { 3 - 8 } & & Efek & tempiris & Efek & t-empiris & Efek & t-empiris \\
\hline 1 & Efikasj-diri (Eta-1) & - & - & - & - & - & - \\
\hline 2 & Kematangan karir (Eta-2) & 0,17 & $4,41^{*}$ & 0,10 & $2,91^{*}$ & 0,21 & $4,52^{*}$ \\
\hline 3 & Prestasi akademik (Eta-3) & 0,05 & $2,02^{*}$ & 0,02 & $1,65^{*}$ & 0,01 & $1,67^{*}$ \\
\hline
\end{tabular}

Keterangan : ${ }^{t}>1,96=$ Signifikan

6. Efek langsung efikasi-diri terhadap kematangan karir 0,26 nilai-t , 4,25 adalah signifikan. Erek langsung efikasidiri terhadap prestasi akademik 0,12 nilai-t 2,14 , 1,96 adalah signifikan. Efek langsung prestasi akademik terhadap kematangan karir 0,31 nilai-t4,41 adalah signifikan. Kesimpulan terdapat efek langsung efikasi-diri terhadap kematangan karir, efikasi-diri terhadap prestasi akademik, dan prestasi akademik tehadap kematangan karir. Efek tidak langsung efikasi-diri terhadap kematangan karir melalui prestasi akademik 0,04 nilai-t 1,92 tidak signifikan. Kesimpulan bahwa tidak terdapat efek tidak langsung efikasi-diri terhadap kematangan karir. 


\section{Diskusi}

Model teoritis tidak didukung data empiris. Ferdinand (2002) menyatakan jika model tidak fit, maka harus dilakukan modifikasi. Hasil analisis atas mode! modifikasi menunjukkan bahwa model teoritis didukung data. Layanan bimbingan, persepsi penjurusan, riwayat hidup, efikasidiri dan prestasi akademik berpengaruh terhadap kematangan karir. Pengaruh langsung dan tidak langsung layanan bimbingan terhadap kematangan karir signifikan. Temuan ini sesuai dengan teori Super (1994) dan hasil studiAbdullah ( 1985 ), Abimanyu (1990), Partino (1990). Pritchard (1984), Pavlak dan Post-Kammer (1985).

Layanan bimbingan berpengaruh positif terhadap efikasi-diri, prestasí akademik dan kematangan karir. Temuan ini sejalan dengan teori Bandura (1997) bahwa keyakinan dan tingkah laku individu dapat diubah melalui berbagai metode, seperti layanan bimbingan. Layanan bimbingan sebagai agen perubahan, terutama merubah tingkah laku yang tidak sesuai dengan norma sekolah dan masyarakaL Jadi, jelas bahwa layanan bimbingan memberikan sumbangan yang berarti terhadap perubahan tingkah laku.

Studi ini menemukan bahwa layanan bimbingan berhubungan signifikan dengan prestasi akademik. Temuan ini senada dengan hasil studi Abdullah (1986), Abimanyu (1990), Partino (1990) dan Pritchard (1984). Layanan bimbingan, terutama bimbingan belajar ditujukan agar peserta didik memiliki prestasi optimal. Individu yang mengalami kesulitan belajar dibimbing agar dapat menyesuaikan dengan kelompok belajarnya.

Persepsi penjurusan berpengaruh positif terhadap efikasi-diri, prestasi akademik dan kematangan karir. Bimbingan belajar berupaya membantu siswa memahami seluk beluk pembelajaran. Layanan ini membantu siswa menyadarkan diri atas kemampuannya, baik kelebihan maupun kekurangannya. Kesadaran diri membawa individu menemukan keyakinan diri. Keyakinan diri tinggi akan mengarah pada kesanggupan mengerjakan suatu tugas dengan sukses, sedang keyakinan diri rendah mengakibatkan menarik diri. Jadi, pemahaman diri yang memadai akan membantu dalam mempersepsi tentang penempatan dirinya.

Temuan penelitian ini menunjukkan bahwa persepsi penjurusan di SMA berpengaruh langsung terhadap kematangan kari. Temuan ini sesuai dengan studi Gillies (2003), Hill dan Kellems (2002). Jika persepsi terhadap penjurusan akurat., maka siswa menerima penjurusan dengan senang. Jika persepsi mereka tidak sesuai, maka siswa tidak sepenuhnya menerima penjurusan tersebut. Bentuk protes siswa adalah tidak masuk sekolah berhari-hari setelah kenaikan kelas atau pindah jurusan yang diminati ke sekolah yang mutunya lebih rendah. Jadi persepsi penjurusan merupakan salah satu variabel penting dalam model kematangan karir.

Riwayat hidup berpengaruh positif terhadap efikasi-diri, prestasi akademik dan kematangan karir. Bukti temuan penelitian kaitan riwayat hidup dengan efikasi-diri, prestasi akademik, dan kematangan karir belum ditemukan. Namun, kaitan diantara aspek-aspek tersebut dapat dijelaskan. Aspek riwayat hidup dalam pengujian hipotesis ini meliputi keaktifan dalam kegiatan organisasi di sekolah (OSIS dan non-OSIS), kegiatan organisasi di lingkungan tempat tinggal. Individu yang aktif dalam organisasi lebih memiliki kepercayaan diri yang tinggi. Kepercayaan diri tinggi akan menggerakkan kesanggupan diri untuk mengerjakan sesuatu tugas. Jadi, tingkat partisipasi dalam organisasi akan memberikan dukungan terhadap efikasi-diri. Kegiatan organisasi, baik di sekolah maupun đi luar sekolah, pada hakekatnya merupakan proses pembelajaran individu yang bersangkutan. Proses belajar terjadi di lingkungan sekolah, keluarga dan masyarakat berlangsung sepanjang hayat. Proses belajar terse but meliputi aspek-aspek kognitif, afektif dan performansi. Hasil-hasil belajar di dalam aspek-aspek tersebut akan dialihkan pada berbagai kegiatan hidup lainnya, seperti lebih khusus dalam 
menyelesaikan tugas-tugas sekolah. Jadi, dapat dinyatakan bahwa tingkat keaktifan individu dalam berbagai kegiatan atau organisasi berhubungan erat dengan prestasi akademik of sekolah.

Riwayat hidup berpengaruh langsung dan tidak langsung terhadap kematangan karir. Temuan ini sesuai dengan teori Super (1994), studi Super dan Overstreet (dalam Osipow, 1983) tentang keaktifan siswa dalam organisasi di sekolah. Kenyataan ini dapat ditelusuri, mengingat bahwa siswa yang menduduki posisi penting dalam suatu organisasi di sekolah dan di luar sekolah pada umumnya memiliki kelebihan daripada mereka yang tidak terlibat langsung dalam organisasi. Jadi, riwayat hidup merupakan salah satu variabel independen yang ikut membentuk model kematangan karir.

Efikasi-diri berpengaruh secara positif terhadap prestasi akademik dan kematangan karir. Hasil ini sejalan dengan temuan Lent dkk (1987), Rangel dkk (1990), Multon dkk (1991), Partino (1999) dan Pietsch dkk (2003). Para ahli mengakui relevansi teori efikasi-diri untuk memahami dan meramakkan kematangan karir dan prestasi akademik (Multon dkk, 1991; Hackett dan Betz, 1981) Efikasi-diri tinggi sebagai motor pembangkit yang mendorong individu mengerjakan tugas dengan sukses. Efikasi-diri menggerakkan motivasi untuk menyelesaikan tugas. Motif berprestasi mendorong individu berhasil dalam menyelesaikan tugas-tugas (Martaniah, 1982). Jadi, efikasi-diri memainkan peran penting dalam kaitannya dengan prestasi akademik.

Efikasi-diri berpengaruh positif terhadap kematangan karir. Hasil studi ini sesuai dengan temuan Hacket (1995), Lent dkk. (1987). Hackett \& Betz (1981), Lent \& Hackest (1987). Partino (1999), dan Rotberg dkk. (1987). Bandura (1997) menegaskan bahwa individu yang memiliki effkasi-diri tinggi akan lebih berhasil dalam menyelesaikan pekerjaannya daripada yang memiliki efikasi-diri rendah.

Pengaruh efikasi-diri terhadap kematangan karir dapat dikaji dari segi proses kognitif. Efikasi-diri mempengaruhi pola-pola pikiran yang mendasari tingkah laku (Bandura, 1997). Individu yang memiliki keyakinan efikasi-diri tinggi memiliki perspektif ke depan. Tujuan hidup individu dipengaruhi oleh penilaian diri tentang kapabilitasnya. Semakin kuat efikasi-diri, semakin tinggi tujuan hidupnya, dan semakin memiliki komitmen untuk mencapai tujuan. Efikasi-diri rendah dalam kaitannya dengan tingkah laku, mengakibatkan individu bertingkah laku menghindar (Betz \& Taylor, 2001).

Prestasi akademik berpengaruh positif terhadap kematangan karir. Temuan ini sesuai dengan teori Super (1994) dan hasil studi Super \& Overstreet (dalam Osipow, 1983), Abimanyu, (1990), Partino (1990), dan West (1988). Individu yang mencapal prestasi akademik tinggi cenderung mempunyai wawasan luas, terutama mata pelajaran sekolah. Jadi, prestasi akademik mempunyai peranan penting dalam model kematangan karir.

\section{Penutup}

Hasil penelitian ini menunjukkan suatu model kematangan kari siswa SMA Kota Jayapura Provinsi Papua. Model ini menggambarkan bahwa kematangan karir dipengaruhi oleh faktor-faktor layanan bimbingan, persepsi penjurusan, riwayat hidup, entkasi-diri dan prestasi akademik. Jemuan ini secara teoritis memberi sumbangan bermakna terhadap pengembangan psikologi karir.

Berdasarkan hasil penelitian of atas, penulis bermaksud memberikan sejumlah saran.

1. Faktor-faktor penentu kematangan karir periu dipahami dan mendapat perhatian berbagai pihak yang berkaitan dengan siswa SMA (khususnya konselor dan guru mata pelajaran) dalam upaya membantu memudahkan dan meningkatkan perkembangan karir siswa.

2. Efek langsung efikasi-diri dan prestasi akademik terhadap kematangan karir merupakan indikator penting. Konselor dan guru mata pelajaran dapat 
merancang guna menumbuhkan keyakinan dan kepercayaan diri siswa dan pada gilirannya akan meningkatkan keyakinan efikasi-dirinya.

3. Peneititan Ianjutan periu mempertimbangkan aspek-aspek metodologi. Studi dengan rancangan eksperimen dan kualitatif, pelibatan variabel- variabel independen lain (jenis keiamin, konsep dirl, status sosial ekonomi, iocus of controi), mempertuas variasi subjek (SMP, Sekolah Menengah Kejuruan/SMK, perguruan tinggi, kursuskursus keterampilan) dan memperkaya variasi wilayah penelitian (perkotaan. pinggiran, dan pedesaan), diharapkan akan mampu memberikan gambaran kematangan karir yang lebih memadai.

\section{DAFTAR PUSTAKA}

Abdullah, A.E. 1986. Pengaruh Paket Bimbingan Karir Terhadap Kematangan Karir Siswa SMA Di Sulawesi Selatan. Bandung: Makalah Konvensi Nasional Ikatan Petugas Bimbingan indonesia.

Abimanyu, S. 1990. Hubungan antara beberapa faktor sosial dan prestasi, jenis kelamin, dan lokus kendali dengan kematangan karir siswa Sekolah Menengah Atas. Disertasi Doktor. Maiang: Fakultas Pasca Sarjana IKIP Malang. .

Bandura, A 1997. Solf-Efficacy: The Exercise of Control. New York: W.H.Freeman and Company.

Betz, N.E. and Hackett, G. 1981. The Relationship Of Career-Related SelfEfficacy Expectations To Perceived Career Options In Coilege Men And Women. Journal of Counseling Psychology, 27, 44-62.

Betz, N.E. nad Taylor, K.M. 2001. Manuai For The Career Decision Self-Efficacy Scale And Career Decision Scale
Self-Efficacy Short Form. Columbus: Deopartment of Psychology. The Ohio State University.

Bolies, R. N. 1993. A Practical Manual For Job Hunters \& Career-Changer: The 1993 What Color is Your Parachutes? Califomia: Ten Speed Press.

Brown, D. 1996. "Summan, comparision, and critique of the major theories". Dalam Duane Brown dan Linda Brooks (Ed). Career Choice and Development, 338-363. San Fransisco: Jossey-Bass Publisher.

Casto, M.L. 2004. What is career?. Guest Article Archive. Guest @ AghilhaM. http:/hww.getsmartseries.com/.

Coertse, S., and Schepers, J.M. 2004. Some Personality and Cognitive Cor elates of Career Maturity.SA Joumal of Industrial Psychology,30,2. www.siopsa.org.za/Conference/04 conference archives.htm -8k

Creed, PA. and Patton, W. 2003. Predicting Two Components Of Career Maturity In School Based Adolescents. Joumal of Career Development, 29, 277-290.

Crites, J. 1974. The Career Maturity inventory. Dalam Donald E Super (Ed.), Measuring Vocational Maturily For Counseling And Evaluation. Monograph of the Nationai Vocational Guidance Association, 25-29.

Crites, J. 1986. Career Counseling: Models, Methods, And Materials. New York: McGraw-Hill Book Company.

Departemen Pendidikan dan Kebudayaan 1975. Kurikulum Sekolah Menengah Umum Tingkat Atas. Jakarta: Direktorat Jenderal Pendidikan 


\section{Dasardan Menengah.}

Departemen Pendidikan dan Kebudayaan 1996. Kurikulum Sekolah Menengah Umum: Petunjuk Teknis Pengelolaan Bimbingan Dan Konseling. Jakarta: Direktorat Jenderal Pendidikan Dasardan Menengah.

Esbroeck, R.V. \& Watts, T. 1998. New Skilt For A Holistic Careers Guidance Model. The International Careers Journal. (June 26, 1998 http.//www,careers-journal.com).

Ferdinand, A 2002. Structural Equation Modeling Dalam Penelitian Manajemen: Apllkasi Model-Model Rumit Dalam Penelitlan Untuk Tesis S-2 \& Disertasi S-3. Semarang: Badang Penerbit Universitas Diponegoro.

Gillies, R.M. 2003. The Behaviors, Interactions, And Perceptions of Junior High School Students During Small-Group Leaming. Joumal of Educational Psychology. 95, 137147.

Gysbers, N. 1998. Career Development: The Contemporary Scene And The Future. Highlight: An ERIC/CAPS Digest. MI:ERICC Learinghouse On Counseling And Personal Service, The University of Michigan.

Hackett, G. 1985. The Role Of Mathemalics Self-Efficacy in The Choice Of MathRelated Majors of College Women And Men: A Path Analysis. Jiournal of Counseling Psychology. 32, 47-56.

Hackelt, G. and Betz, N.E. 1981. A SelfEfficacy Approach To The Career Development Of Woman. Journal of Vocational Behavior, 18, 327-339.

Hammel, J. 2001. Life Story Creation Page. Mailto: hammel@uic.edu. 12 Januari 2001.
Hill, C.E. \& Kellems, I.A. 2002. Development And Use of The Helping Skills Measure Toraja Assess Client Perceptions of The Effects of Training And of Helping Skills In Sessions. Joumal of Counseling Psychology, 49. 264-271.

Joreskog, K.G. \& Sorbon, D., 1996. LISREL 8.3: User's Reference Guide. Chicago: Scientific Software International.

Lent, R.W., Brown, S.D., and Larkin, K.C. 1987. Comparison Of Three Theoretically Derived Variables in Predicting Career And Academic Behavior: Self-Efficacy, Interest Congruence, And Consequential Thinking. Journal of Counseling Psychology, 30, 347-382.

Lunedborg, D.J., Osborn, W.L. \& Miner, C.U. 1997. Career Maturity And Personality Preference of MexicanAmerican And Anglo-American Adolescent. Journal of Career Development, 23, 202-213.

Luzzo, D.A. 1995. Gender And Ethnic Differencees in The Perception $O$ Barriers To Career Development. Denver: American Counseling Association Conference Paper.

Martaniah, S.M. 1982. Motif Sosial Remaja Jawa Dan Keturunan Cina: Suatu Studi Perbandingan. Disertasi Doktor Psikologi. Yogyakarta: Universitas Gadjah Mada.

Mau, W.C. 2001. Cultural Differences in Career Decision Making Styles And Self-Efficacy, Joumal of Vocational Behavior, 57, 365-378.

Multon, K.D., Brown, S.D., Lent, R.W.1991. Relation of Self-Efficacy To Academic Performance. Journal of Counseling Psychology, 38, 30-38. 
Munandir. 1996. Program Bimbingan Karir $D$ Sekolah. Jakarta: Departemen Pendidikan dan Kebudayaan.

Naidoo, A V. 1998. Career Maturity: A Review Of Four Decades Or Research. Bellville-South Africa: University of the Westem Cape.

Naidoo,A.V., Bowman, S.L. \& Gerstein, L.H. 1998. Demographics, Causality. Work Salience, And The Career Maturity of African-American Student: A Causal Model. Joumal of Vocational Behavior, 53, 15-27.

National Career Development Association (NCDA), 2003. Career Development: A Policy Statement Or The National Career Development Association Board Of Directors. NCDA

Osipow, S.H. 1983. Theories Or Career Development. Englewood Cliffs, New Jersey: Prenrice-Hail Inc.

Partino, H.R. 1990. Pengaruh Balikan Hasil Tes Bakat Dan Minat Terhadap Kematangan Karir Siswa SMA DI Malang. Tesis Magister. Malang: Fakultas Pasca Sarjana.

Partino, H.R. 1999. Hubungan Antara Efikasi-Diri Dengan Unjuk Kerja: Suatu Studl Meta-Analisis. Psikologika: Jumal Pemikiran dan Ponelitian Psikologi, 8, 53-68.

Pavak, M.F and Post-Kammer, P. 1985. The Effect Of A Career Guidance Program On The Career Maturity And Self-Concept Of Delinquent Youth. Joumal of Vocational Behavior, 26. 41-54.

Pietsch, J., Walker, R., and Chapman, E. 2003. The Relationship Among SelfConcept, Seif-Efficacy, And Performance In Mathematics During Secondary Schooi. Journal of Educational Psychology, 3, 589-603.
Post-Kammer, P. \& Smith, P.L. 1986. Sex Difference In Math And Science Career Self-Efficacy Among Disadvantaged Student. Joumal of Vocational Behavior, 29, 89-101.

Pritchard, D.H. 1984. Career Guidance: An Approach To Comprehensive Improvements. Joumal of Career Education, 10, 158-157.

Rangel, E.B., Church, A.T., Szendre, D., and Reeves, C. 1990 . Self-Efficacy In Relation To Occupational Consideration And Academic Performance In High School Equivalency Students, Joumal of Counseling Psychology, 4, 407-418.

Rojewski, J.W., Wicklein, R.C., \& Schell, JW. 1995. Effects Of Gender And Academic-Risk Behavior On The Career Maturity of Rural Youth. Journal of Research in Rural Education, 11, 456469.

Rotberg, H.L., Brown, D., and Ware, W.B. 1987. Career Self-Efficacy Expectation And Perceived Range of Career Options In Community College Students. Journal of Counseling Psychology, 34, 164170.

Super, D.E. 1994. Life Span, Life Space Perspective On Convergence. Dalam Mark L. Savickas \& Robert W. Lent (Eds.). Convergence in career development theories: Implementation for science and practice, 63-74. PaloAlto: Consulting Psychologists Press.

Walgito, B. 2002. Psikologi Sosial: Sualu Pengantar. Yogyakarta: Andi Offset.

West, D.K. 1998. Comparisons of Career Maturity And its Relationship With Academic Performance. Journal of American Indian Education, 27, 213 322. 